\title{
COMPARATIVE ANALYSIS OF KNOWLEDGE TRANSFER MANAGEMENT MODELS OF BUSINESS SUCCESSION
}

\author{
L'ubor JUSKO
}

Department of Business Finance, Faculty of Business Management, University of Economics in Bratislava, Slovakia

\section{Nikoleta HUTMANOVÁ}

Department of Business Finance, Faculty of Business Management, University of Economics in Bratislava, Slovakia

\section{L'udovít MOLITORIS}

Department of Business Finance, Faculty of Business Management, University of Economics in Bratislava, Slovakia

Received: 17. January 2021 Reviewed: 02. March 2021 Accepted: 30. March 2021

\begin{abstract}
There are insufficient models outlining elements affecting knowledge transfer during business succession. This study brings together four knowledge transfer models representing different environments and outlines their similarities and differences as well as additional factors influencing the process of knowledge transfer. Upon analysis of the discussed models, other factors affecting the smooth transfer of knowledge are identified, and suggestions for their enhancement are proposed. This study and comparison of the models determine how the knowledge is generated and shared. According to this, the specific aspects were identified, and additional factors were outlined.

The presented knowledge management models and their essential components are in this whole study presented as an elaboration of ways how to facilitate the exchange of accumulated knowledge. Furthermore, the study also deals with transformational changes in the discussed models and how they affect family firms' whole business succession process. The description and analysis of a smooth transfer in this study help ensure an overall competitive advantage of a family firm.
\end{abstract}

Keywords: family business, knowledge transfer, succession process

JEL Classification: J33, C52, M51 


\section{Introduction and theoretical background}

Transfer of knowledge and skills represents one of the main challenges during the business succession, which is essential for sustaining and enhancement of the performance of the family business. Kumar and Ganesh define knowledge transfer as a process of exchanging explicit or tacit knowledge between two agents. One agent purposefully receives and uses the knowledge provided by another (Kumar et al., 2009). Business succession in family firms has been one of the most investigated topics through theoretical, empirical and anecdotal studies (Brockhaus, 2004; Sharma, 2004). Similarly, Malinen considers knowledge transfer one of the top three issues in family succession, taxation, and finding the proper successor (Malinen, 2004). However, there is insufficient research focused on the knowledge transfer between the incumbent (founder of the family firm) and successor (person taking over the business) but also elements influencing the overall process of knowledge generation and its sharing.

The purpose of this study is, therefore, (1) to determine how the knowledge is generated and shared with the next generation, (2) to identify common aspects in the knowledge transfer process, (3) to outline additional factors having an influence on the smooth transfer of knowledge from incumbent to the next generation (successor) and to (4) make suggestions for the improvement of the existing knowledge transfer models.

\section{Material and methods}

As research material, several case studies were used, and the data analysis contained a comparison and contrast of different succession planning models in family firms. Succession has been the most widespread form in Western Europe over the last 20 years and is the focus of interest mainly of family firms than non-family firms (Mandl, 2008). Succession in a family firm transfers management and ownership of a business to a new generation (e.g. family members). Such a transfer may also involve family assets as part of the process. Effective integration and management of the family component have a decisive influence on the success of the succession process (Sharma, 2001).

Succession is a significant challenge for the longevity of family firms (Olson et al., 2003). Along with the developmental trajectory of the business, succession can occur in response to or anticipation of specific transformational changes (Bjuggren et al., 2001). These changes may be related to a significant revision of the business strategy of the family firm, which in turn may require a change and adaptation of internal structures and processes to support a new direction (Duh et al., 2009).

Succession planning is the deliberate and systematic effort made by the leadership of organisations to recruit, develop and retain individuals with a range of leadership competencies capable of implementing current and future organisational goals (Leibman et al., 1996). It can also be defined as the attempt to plan for the correct number and quality of managers and key-skilled employees to cover retirements, death, severe illness or promotion, and any new positions created in future organisation plans. It helps calculate critical resources, including succession planning and career pathing of employees (Beaver et al., 2004). Succession in family businesses can also represent the transfer of the leadership from the owner-founder to a successor who is or is not a family member; if he is not, he is a professional manager.

The succession process is commonly described as consisting of several phases that most often contain initiation/preparation, integration, joint management, and fi- 
nally, the predecessor's retirement (Cadieux et al., 2002).

When the question about business succession occurs, the owner of the family firm has two options. One is to keep the business within the family through the succession, and the other is to sell the family business to an external buyer.

We distinguish succession in family businesses as internal and external. If at least one person comes from a family union or is married into a given family, the internal succession occurs. If this is not the case, it represents the external succession (Spelsberg et al., 2012). A classic example of internal succession is the management transfer from parents to descendants. With external succession, management is transferred to good acquaintances, employees, or foreign entities.

In this context, the terms "Family Buy-Out" (FBO) are often used, i.e. succession within the family, "Management Buy-Out" (MBO) for the transfer of the company to employees and "Management Buy-In" (MBI) for the purchase to an external person (Howorrth et al., 2004).

\section{Results and discussion}

\section{Knowledge management and knowledge transfer models}

In an economy where the only certainty is uncertainty, knowledge is the one sure source of lasting competitive advantage (Nonaka, 1991). Grant suggests that knowledge is mainly the significant competitive asset that an organisation possesses. Knowledge is also a strategic resource, and knowledge management integrates both the operational and strategic perspectives of any organization (Grant, 1996; Nonaka, 1994).

Knowledge is a significant resource for competitive advantage and innovation. Many family businesses do not survive the transfer to the next family generation; knowledge creation is crucial for securing family businesses' viability and long-run performance in succeeding family generations. Systematic research on knowledge and knowledge creation in family businesses is insufficient (Chirico, 2008; Zahra et al., 2007).

Before transferring the knowledge to the next generation, its preservation constitutes an essential part of knowledge management. Even if the firms reorganise themselves, the organisational memory value can be underestimated and, often, experience is not stored; thus, relevant information and knowledge are lost. Suppose the firm's knowledge creation and development depend on the bases supplied by previous knowledge. In that case, firms that wish to manage their knowledge to be available and accessible in the future must establish mechanisms to retain this knowledge basis (Probst, 2002).

For efficient knowledge management, there have been several models proposed by the researchers that stipulate how the knowledge is generated and transferred. Four representatives of them reflecting various approaches are discussed below.

\section{Model of Knowledge Transfer Successor's Development in the Family Firm}

Katiuska Cabrera-Suárez, Petra De Saá-Pérez and Desiderio García-Almeida analysed how succession can be effectively managed to take into account the resource-based and the knowledge-based theories of the firm. Based on this analysis, the authors developed a conceptual framework that helps understand the transfer of 
knowledge to the successor of the family firm (Cabrera-Suárez et al., 2001). The model deals with factors about the predecessor, the successor and the relationship between them. The model assumes that the information and knowledge associated with the predecessor are the family business's most valuable resources and capabilities, which support the competitive advantage and can lead to higher performance.

The model considers knowledge as a critical strategic resource of family business encompassing the family's goals, values, and influences. All of these are the deciding factors for the goals of the family business, the way the business performs and the people who participate in it. The tacit knowledge that the founder of an incumbent head of a family business possesses is a source of competitive advantage that distinguishes a family business from a non-family business. The transfer of this knowledge to the successor has strategic importance for the family business. The authors also opine that family businesses' most valuable resources and capabilities are based on the incumbent's information and tacit knowledge. Thus, the most crucial aspect in managing succession is effectively transferring this knowledge to the successor. The authors propose an integrative model for sharing knowledge and the successor's development in the family business firm influenced by the business context and family context.

Figure 1 Model of knowledge transfer and successor's development in the family firm

\section{Model of Knowledge Transfer and Successor's Development in the Family Firm}

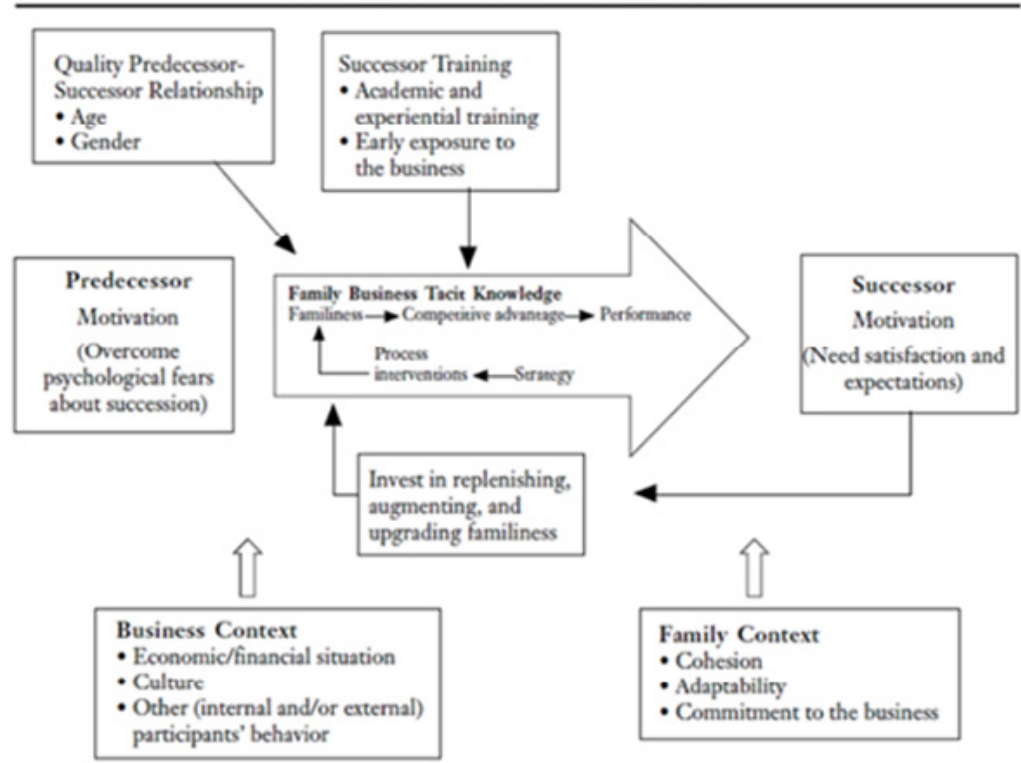

Source: Cabrera-Suárez, K., De Saá-Pérez P., E Garcia-Almeida, D. (2001). The succession process from a resource and knowledge-based view of the firm, Family Business Review. 


\section{Model of Knowledge Transfer Successor's Development in the Family Firm}

Figure 2 Knowledge transfer model in family firms

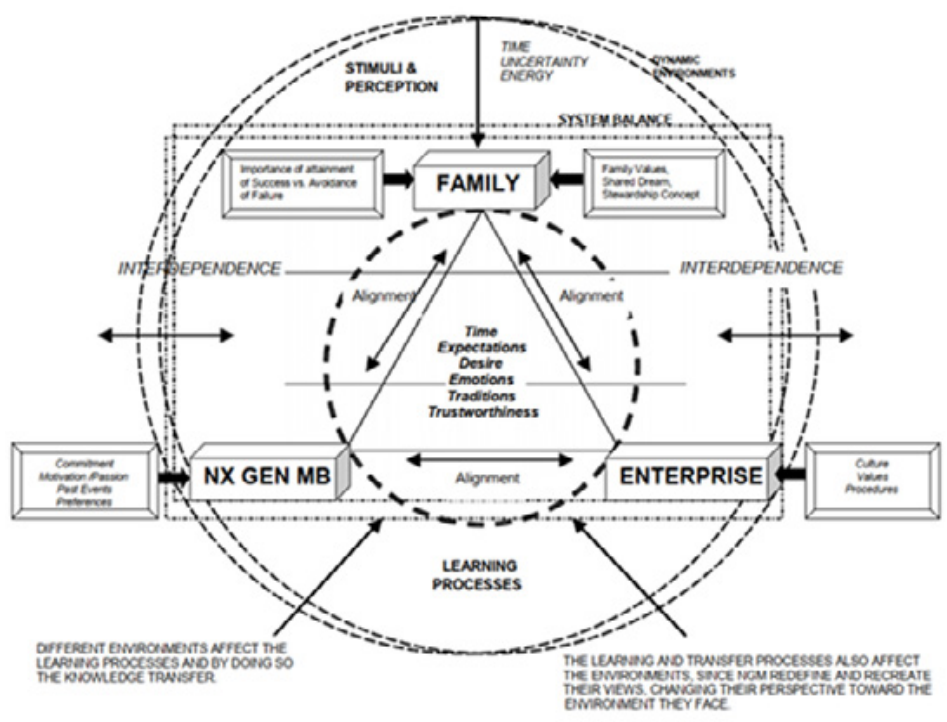

Source: Rosa Nelly Irevinyo-Rodriguez, "Knowledge Iranster Model in FF" presented at the EFMD 35" Conference: Sustaining the Entreprencurial Spirit Over Time, Sept. 2005. Barcelona. Spain.

Source: Trevinyo-Rodriguez, R.N., Tápies, J. (2005). Effective knowledge transfer in family firms. IESE Research Papers. IESE Business School.

The "Knowledge Transfer Model in Family Firms" was presented at the 35th EFMD Conference "Sustaining the Entrepreneurial Spirit Over Time" by Rosa Nelly Trevinyo-Rodriguez, and Josep Tápies. The model determines a complex, interdependent environment affecting the knowledge transfer and learning process between the family, enterprise and Next-Generation Members (NGM) and external dynamic environment (Trevinyo-Rodriguez et al., 2005).

The model considers the family as a reference system containing values, ideas, behaviours, norms and general knowledge, which is transmitted unconsciously to the NGM through traditions from its birth. The successor (or candidates) - NGM has been embedded in the family system since he was born. As the individual develops his personality, habits, and beliefs, the family transmits his particular views and ideologies, memories, and values that preserve certain behaviours, mental maps, norms, and ideas. The same thing happens with the other members embedded in the family system. The enterprise is affected by its operational culture, values and operational procedures. To achieve its ultimate criterion, long-term survival and growth, the system must find different balances depending on the environment it coexists (Trevinyo-Rodriguez et al., 2010).

It must also be considered that the environments are dynamic, changing continuously and being affected by time, uncertainty, energy imposed, past events, etc. 
Furthermore, the system needs to align its elements (actors) with the general ambience. However, this alignment is also cyclical and dynamic, preserved by a sustained cause-effect solid relationship among actors. System Adaptation, Alignment and Actors' Assimilation of knowledge (learning) regarding the environments, and the force of the interrelationship System Balance-Environment-Actors will determine the family firm's survival/death and fit/misfit in the community (Trevinyo-Rodriguez et al., 2010).

\section{Model of Knowledge Creation}

Figure 3 Model of Knowledge Creation

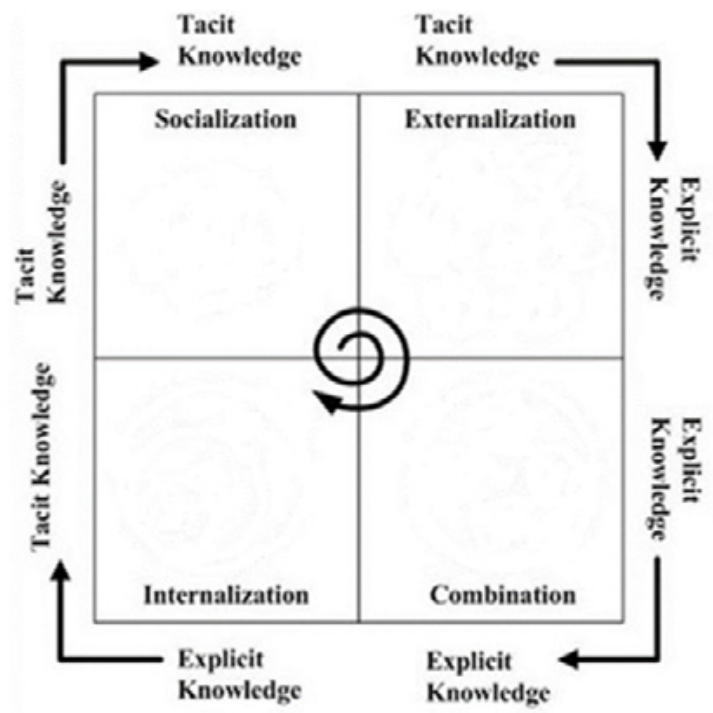

Source: Nonaka, I., E Takeuchi, H. (2019). How Companies Create Continuous Innovation; Oxford University Press: Oxford.

Nonaka and Takeuchi indicated that the generation and creation of knowledge could be categorised into four types: socialisation, externalisation, combination and internalisation (Nonaka et al., 2019). The core of Nonaka's work is a premise that there are two types of knowledge: implicit and explicit. Tacit knowledge is subjective and experience-based knowledge that cannot be expressed in words, sentences, numbers or formulas, often because it is context-specific. This includes cognitive skills such as beliefs, images, intuition and mental models, and technical skills such as craft and know-how. Explicit knowledge has a universal character, is easy to transfer, and can be transmitted in the formal, systematic language (Nonaka et al., 2000; Reychay et al., 2009).

The process that transfers tacit knowledge in one person to tacit knowledge in another person is socialisation. It is experiential, active and capturing knowledge through direct interaction with customers and suppliers outside the organisation and 
people inside the organisation. This depends on having a shared experience and results in acquired skills and standard mental models. Socialisation is primarily a process between individuals. The company's socialisation of tacit knowledge from collective experiences and mental models is disseminated through externalisation (Bell et al., 2020); Nonaka et al., 1998). It represents the articulation of own tacit knowledge of individual - ideas or images in words, metaphors, analogies. A second case is eliciting and translating the tacit knowledge of others - customers, experts, for example - into a readily understandable form, e.g., explicit knowledge. The process of externalisation helps create new knowledge as the tacit knowledge of individuals emerges from within its boundary and becomes collective knowledge (Nonaka et al., 2007). Externalisation is a process among individuals within a group.

Combination (explicit to explicit knowledge) is part of the process that synthesises explicit concepts and brings them to a knowledge base through capturing and integrating new essential explicit knowledge. Such knowledge is further disseminated in organisations in a form of presentations, meeting or emails.

Internalisation is the process of understanding and absorbing explicit knowledge into tacit knowledge held by the individual. The internalisation process transfers organisation and group explicit knowledge to the individual. In this way, individuals use this stage to expand, extend and transform their tacit knowledge, starting a new cycle again.

The model of factors supporting the knowledge transfer process in Vietnamese family businesses

Figure 4 Model of Knowledge Creation

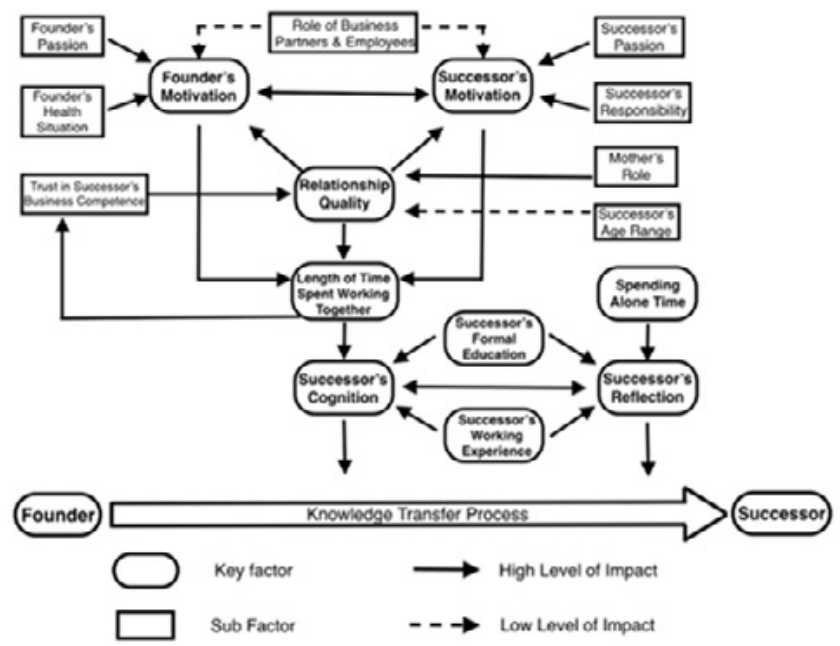

Source: Bell, R., E Pham, T. T. (2020). Modelling the Knowledge Transfer Process between Founder and Successor in Vietnamese Family Business Succession. Journal of Family Business Management. 
The model developed by Robin Bell and Thanh Trung Pham highlights the factors that influence the knowledge transfer process in the Vietnamese family business context. It provides additional insights to research in the family business field by suggesting that the successor's cognition and reflection directly influence the knowledge transfer process from founder to successor. In contrast, the remaining factors indirectly influence this process.

The model suggests that the knowledge transfer actively involves the members of an organisation and its technologies in terms of tasks and processes. In business successions, both the incumbent, successor, and the organization are involved in knowledge transmission, absorption, and reuse.

This model identifies the influence of factors, some of which are not commonly presented in western family business literature. These include the importance of the role of the mother in mediating the relationship quality between the founder and the successor and the successor pursuing education and external work experience to improve their cognitive and reflective abilities. The need for affinity between family members is also highlighted as necessary (Bell et al., 2020).

\section{Comparison of the knowledge transfer models}

Due to the variety of different industries involved, there are no existing knowledge transfer models that could be generally applicable and representative for all of them. However, it is possible to identify similar features common to all presented models, which could be used in different sectors. Table 1 depicts similarities and differences in the discussed models, aiming for effective knowledge transfer from the incumbent to the successor.

It can be noted that the tacit knowledge - the valuable and highly subjective insights and intuitions are difficult to capture and share. It represents a common factor deemed as the source of values, ideas, behaviours, norms or general knowledge (Szulanski, 2000).

Another aspect present in each model is a realisation that the knowledge is created and transferred in a dynamic, changing environment which represents a phenomenon that inherently involves interdependencies and asymmetries between providers and recipients of knowledge and difficulties during different knowledge transfer stages (Caloghirou et al., 2004; Contractor et al., 1988; Davasindhu, 2002).

Due to the variety of the aspects addressed by the presented models, there are several similarities and differences, which allow further analysis and suggestion for their enhancement. 
Table 1 Similarities and differences between each of the knowledge transfer models

\begin{tabular}{|c|c|c|}
\hline Authors & Similarities & Differences \\
\hline Cabrera-Suarez et al & \multirow[t]{4}{*}{$\begin{array}{l}\text { Tacit knowledge deemed } \\
\text { as relevant for knowledge } \\
\text { sharing } \\
\text { - Focus on knowledge } \\
\text { creation and sharing in a } \\
\text { dynamic environment }\end{array}$} & $\begin{array}{l}\text { - Age and gender } \\
\text { moderate relationship } \\
\text { between incumbent and } \\
\text { successor } \\
\text { - The need for experiential } \\
\text { and academic training of } \\
\text { the successor } \\
\text { - Early exposure to } \\
\text { business as facilitator of } \\
\text { the knowledge transfer }\end{array}$ \\
\hline Trevinyo-Rodriguez & & $\begin{array}{l}\text { - Operational culture, } \\
\text { values and operational } \\
\text { procedures representing } \\
\text { important factors affecting } \\
\text { knowledge transfer } \\
\text { - Stewardship concept to } \\
\text { be applied in knowledge } \\
\text { generation and sharing }\end{array}$ \\
\hline Nonaka and Takeuchi & & $\begin{array}{l}\text { Knowledge transfer } \\
\text { modelled as a spiral } \\
\text { process (socialisation, } \\
\text { externalisation, } \\
\text { combination, } \\
\text { internalisation) } \\
\text { - All four modes to be } \\
\text { organisationally managed } \\
\text { and dynamically } \\
\text { interacted for } \\
\text { organisation's knowledge } \\
\text { creation }\end{array}$ \\
\hline Bell and Trung Pham & & $\begin{array}{l}\text { - The role of successor's } \\
\text { mother in knowledge } \\
\text { transfer } \\
\text { - Significance of } \\
\text { interrelation of the } \\
\text { successor's cognition and } \\
\text { reflection in the } \\
\text { knowledge transfer } \\
\text { process } \\
\text { - Importance of the } \\
\text { relationship quality } \\
\text { between the successor } \\
\text { and the founder }\end{array}$ \\
\hline
\end{tabular}

Source: Own processing 


\section{Suggestions for the improvement of the existing knowledge transfer models}

While the discussed knowledge transfer model focuses on knowledge creation and knowledge sharing, considering tacit knowledge as the driving force, several improvements can be proposed for their enhancement and broader considerations or elements to be reflected. In particular, additional accentuation of the role of intellectual capital, which could be conceptualised and defined as a set of bundled capabilities/ competencies and knowledge resources, which are linked and mutually dependent and its importance and capitalisation on its benefits is usually ignored by the managers.

This is further emphasised in the knowledge transfer model designed by Rastogi, which adopts a holistic approach in defining intellectual (Rastogi, 2003) capital as the result of dynamic interrelationships and conjoint interaction among its three components. These are structural capital (knowledge created and stored in organisation technical devices - IT infrastructures, routines and processes), external capital (brands, customer loyalty, distribution channels, and financial institution collaboration) and human capital (personal knowledge, experience, the expertise of the members of the organisation, some may also possess owner-managerial spirit).

Chirico and Salvato recognise enablers of dynamic organisational adaptation as an essential element to the sustainable competitive advantage of the family firms (Chirico et al., 2008). The model of Knowledge integration and dynamic organizational adaptation in family firms highlights the importance of recombining knowledge through integrating knowledge among family members to develop capabilities and competitiveness over time. A successful knowledge transfer must hence ensure the ability to integrate knowledge (internal social capital), potential obstacles to integrating knowledge (relationship conflicts), willingness to integrate knowledge (affective commitment to change). They conclude that only those family firms characterised by high levels of internal social capital, affective commitment to change, and low levels of relationship conflicts, will successfully adapt to dynamic markets.

Additionally, Martínez, Galván and Palacios consider trust between family members, commitment to the family business, intergenerational and intragenerational relationship, psychological ownership of the family business, successor's aspects and training, predecessor involvement in the successor training, organisational culture and relationships within the family business associations as the main factors influencing knowledge transfer in family firms (Martinez et al., 2013). In particular, they deem the organizational culture a critical factor in building and reinforcing knowledge management in organisations as it impacts how members learn, acquire and share knowledge (Rai, 2011).

Finally, Boyd, Royer, Pei and Zhang, in their study of actors having an impact on knowledge transfer in inter-generational succession in a family business, conclude that knowledge development encompasses idiosyncratic knowledge. For example, detailed knowledge about time- and location-specific conditions that may not be formalised (Boyd et al., 2012), subject-related experiential knowledge, i.e. knowledge depending on skills regarding a particular material/product such as the knowledge of individuals in a specific field of arts or craftsmanship and network-related experiential knowledge (Patriotta, 2007; Royer et al., 2008).

\section{Conclusion}

Knowledge management and knowledge transfer should be seen as a complex, long-term process of capacity building of the successor contributing to the devel- 
opment of managerial competencies and understanding of the business. In this regard, explicit and implicit knowledge (of the incumbent, employees, etc.) constitute factors, which can substantially contribute to ensuring the survival of the family firm in the hands of the successor by endowing them with necessary managerial and professional competencies. Moreover, a smooth transfer of the strategically valuable knowledge and skills from one generation to the next is vital for sustaining the competitive advantage of the family firm in the market environment.

The presented models demonstrate how the knowledge can be embraced in the family firm to achieve its efficient transfer in a dynamic environment and facilitate the overall learning process of the successor. Yet further consideration of the intellectual capital and its components, business (organisational) culture and characteristic, subject- and network-related knowledge also should be reflected in the updated knowledge management models. Future models should also elaborate on ways to facilitate the exchange of knowledge accumulated by the family members and provide for their integration in the business succession process. This would allow timely creation of a new understanding of the successor and encouragement of innovations.

\section{References}

Beaver, G. \& Hutchings, K. (2004). The big business of strategic HRM in SMEs, HRD in Small Organisations, Routledge Research Studies in HRD Series, Routledge, London, p. 81. ISBN 9780415439879.

Bell, R., \& Pham, T. T. (2020). Modelling the Knowledge Transfer Process between Founder and Successor in Vietnamese Family Business Succession. Journal of Family Business Management. https://doi.org/10.1108/JFBM-03-2020-0024

Bjuggren, P.O., \& Sund, L.G. (2001). Strategic Decision Making in Intergenerational Successions of Small- and Medium-Size Family-Owned Businesses. Family Business Review. https://doi.org/10.1111/j.1741-6248.2001.00011.x

Boyd, B., \& Royer, S. (2012). The suitability of internal versus external successors: relevant knowledge types in family business succession, International Journal of Management Practice, Vol. 5 No. 4. 5(4), 361-382. https:/ / doi.org/10.1504/IJMP.2012.050315

Brockhaus, R.H. (2004). Family Business Succession: Suggestion for Future Research. Family Business Review. https://doi.org/10.1111/j.1741-6248.2004.00011.x

Cabrera-Suárez, K., De Saá-Pérez P., \& Garcia-Almeida, D. (2001). The succession process from a resource and knowledge-based view of the firm, Family Business Review, Vol. 14, No. 1, pp.37-48. https:// doi.org/10.1111/j.1741-6248.2001.00037.x

Caloghirou, Y., Kastelli. I., \& Tsakanikas, A. (2004). Internal capabilities and external knowledge sources: complements or substitutes for innovative performance? Technovation, 24 (1), pp. 29-39. https:/ / doi.org/10.1016/S0166-4972(02)00051-2

Cadieux, L., Lorrain, J., \& Hugron, P. (2002). Succession in Women-Owned Family Businesses: A Case Study. Family Business Review. https://doi.org/10.1111/j.17416248.2002.00017.x 
Contractor, F. J., \& Lorange, P. (1988). Cooperative Strategies in International Business. Lexington Books. ISBN: 0669149276.

Dayasindhu, N. (2002). Embeddedness, knowledge transfer, industry clusters and global competitiveness: A case study of the Indian software industry. Technovation, 22(9):551-560. https:/ / doi.org/10.1016/S0166-4972(01)00098-0

Duh, M., \& Tominc, P., \& Rebernik, M. (2009). The Importance of Family Enterprises in Transition Economies: Is It Overestimated? Eastern European Economics - EAST EUR ECON. https://doi.org/10.2753/EEE0012-8775470602

Grant, R. M. (1996). Toward A Knowledge-Based Theory of the Firm. Strategic Management Journal, 17(S2): 109-122. https:/ / doi.org/10.1002/smj.4250171110

Howorth et al. (2004). Buyouts, information asymmetry and the family management dyad. Journal of Business Venturing, Vol. 19, No. 4, pp. 509-34. https://doi. org/10.1016/j.jbusvent.2003.04.002

Chirico, F. (2008). The Creation, Sharing and Transfer of Knowledge in Family Business. Journal of Small Businesses \& Entrepreneurship, p. 413-433. https:/ / doi.org/10.1080/ 08276331.2008.10593433

Chirico, F., \& Salvato, C. (2008). Knowledge Integration and Dynamic Organizational Adaptation in Family Firms. Family Business Review, vol. 21, no. 2, pp. 169-181. https://doi.org/10.1111/j.1741-6248.2008.00117.x

Kumar, A. J. \& Ganesh, L.S. (2009). Research on Knowledge Transfer in Organizations: A Morphology, p. 163. https://doi.org/10.1108/13673270910971905

Leibman M., Bruer, R., \& Maki, B. (1996). Succession Management the next generation of succession planning. Human Resource Planning, 19(3): 16-29. Retrieved from: https:/ / nzbef.org.nz/wp-content/uploads/2019/04/Framework-Succession-Management-Next-Generation.pdf

Malinen, P. (2004). Problems in transfer of business experienced by Finnish entrepreneurs. Journal of Small Businesses and Enterprise Development. 11(1): 130-139. https:/ / doi.org/10.1108/14626000410519164

Mandl, I. (2008). Overview of family business relevant issues, final report, project on behalf of the European Commission, Austrian Institute for SME Research, Vienna. Retrived from:

https:/ /ec.europa.eu

Martínez, A. B., \& Galván, R. S. \& Palacios, T. B. (2013). Entrepreneurial Orientation and Knowledge Transfer: analysis in Spanish family businesses. Tourism \& Management Studies. vol. 12, Nr. 1, 2016, pp. 211-219. DOI: 10.18089/tms.2016.12123

Nonaka, I., \& Toyama, R. (2007). Why Do Firms Differ? The Theory of the Knowledge-Creating Firm, New challenges for managers, pp.13-31, Oxford University Press, 
Oxford. ISBN: 0198036191.

Nonaka, I., \& Takeuchi, H. (2019). How Companies Create Continuous Innovation; Oxford University Press: Oxford, UK. ISBN 0190497025.

Nonaka, I., Toyama, R. \& Konno, N. (2000). SECI, Ba and leadership: A unified model of dynamic knowledge creation, Long Range Planning, Vol. 33 No. 1, pp. 5-34. https:/ / doi.org/10.1016/S0024-6301(99)00115-6

Nonaka, I. \& Konno, N. (1998). The Concept of Ba: Building a Foundation for Knowledge Creation. California Management Review, 40, 40-54. https:/ / doi.org/10.2307/41165942

Nonaka, I. (1991). The knowledge-creating company. Harvard Business Review, 96-104. Retrieved from: https://hbr.org/2007/07/the-knowledge-creating-company

Nonaka, I. (1994). A dynamic theory of organizational knowledge creation. Organization Science, 5(1), 14-37. https://doi.org/10.1287/orsc.5.1.14

Olson, P., Zuiker, V., Danes, S., Stafford, K., Heck, R., \& Duncan, K. (2003). The impact of the family and the business on family business sustainability. Journal of Business Venturing. 18(5), 639-666. https:/ / doi.org/10.1016/S0883-9026(03)00014-4

Patriotta, G. (2007). Organizational Knowledge in the Making-How Firms Create, Use, and Institutionalized Knowledge, Oxford Scholarship Online, Oxford. DOI:10.1093/ acprof:oso/9780199275243.001.0001

Probst, G., Raub, S., \& Romhardt, K. (2002). Managing Knowledge: the building blocks of success. Porto Alegre: Bookman. ISBN: 978-0-471-99768-9.

Rai, R. (2011). Knowledge management and organizational culture: A theoretical integrative framework, Journal of Knowledge Management. https://doi. org/10.1108/13673271111174320

Rastogi, P. N. (2003). The Nature and Role of IC. Journal of Intellectual Capital, Vol. 4,No. 2, pp. 227-248. https:// doi.org/10.1108/14691930310472848

Reychav, I. \& Weisberg, J. (2009). Good for Workers, Good for Companies: How Knowledge Sharing Benefits Individual Employees. Knowledge and Process Management, 16, 186-197. https://doi.org/10.1002/kpm.335

Royer, S., Simons, R., Boyd, B. \& Rafferty, A. (2008). Promoting family: a contingency model of family business succession, Family Business Review, Vol. 21 No. 1, pp. 15-30. https://doi.org/10.1111/j.1741-6248.2007.00108.x

Sharma, P. (2004). An overview of the field of family business studies: Current status and directions for the future. Family Business Review, 17(1), 1-36. https://doi. org/10.1111/j.1741-6248.2004.00001.x

Sharma, P. et al. (2001). Determinants of initial satisfaction with the succession process in family firms: a conceptual model. Entrepreneurship: Theory and Practice. https:// 
doi.org/10.1177/104225870102500302

Spelsberg, H. Weber. (2012). Familieninterne und familienexterne Unternehmensnachfolgen in Familienunternehmen im empirischen Vergleich. Betriebswirtschaftliche Forschung und Praxis, vol. 64, Issue 1, pp. 73. ISSN 2193-1895.

Szulanski, G. (2000). The Process of Knowledge Transfer: A Diachronic Analysis of Stickiness. Organizational Behaviour and Human Decision Processes, Vol. 82, Issue 1, p. 9-27. https:// doi.org/10.1006/obhd.2000.2884

Trevinyo-Rodriguez, R.N., \& Tápies, J. (2005). Effective knowledge transfer in family firms. IESE Research Papers. IESE Business School. Retrived from: https://media.iese. edu/research/pdfs/DI-0865-E.pdf

Trevinyo-Rodríguez, N.R., \& Bontis, N. (2010). Family ties and emotions: a missing piece in the knowledge transfer puzzle. Journal of Small Business and Enterprise Development,17(3), pp. 418-436. https://doi.org/10.1108/14626001011068716

Zahra, S.A.; Neubaum, D.O. \& Larrañeta, B. (2007). Knowledge sharing and technological capabilities: The moderating role of family involvement, Journal of Business Research, Vol. 60 No. 10, pp. 1070-1079. https://doi.org/10.1016/j.jbusres.2006.12.014

Correspondence address:

PhDr. L'ubor Jusko, Department of Business Finance, Faculty of Business Management, University of Economics in Bratislava, Dolnozemská cesta 1, Slovakia, email: lubor.jusko@euba.sk

Mgr. Nikoleta Hutmanová, Department of Business Finance, Faculty of Business Management, University of Economics in Bratislava, Dolnozemská cesta 1, Slovakia, email: nikoleta.hutmanova@euba.sk

Mgr. L'udovít Molitoris, Department of Business Finance, Faculty of Business Management, University of Economics in Bratislava, Dolnozemská cesta 1, Slovakia, email: ludovit.molitoris@euba.sk 